\title{
Evaluation of Total Phenolic Content in Relation to Antioxidant Activity of Brown Algae Cystoseira barbata from Black Sea
}

\author{
EMIN CADAR ${ }^{1}$, RODICA SIRBU ${ }^{1 *}$, ALEF IBRAM ${ }^{2}$, ANA MARIA IONESCU ${ }^{3}$ \\ 'Ovidius University of Constanta, Faculty of Pharmacy, 124 Mamaia Blvd., 900527, Constanta, Romania \\ ${ }^{2}$ Romvac Company S.A., 7 Centurii Road, Voluntari, 77190 Ilfov, România \\ ${ }^{3}$ Ovidius University of Constanta, Faculty of Medicine, 124 Mamaia Blvd., 900527, Constanta, Romania
}

\begin{abstract}
Seaweeds are widely used in the life science as source of compounds with diverse structural forms and biological activities, therefore, potential source of new antioxidant activity. The algae of the Black Sea have not been adequately explored for their potential as a source of bioactive substances. In this context, Brown algae Cystoseira barbata isolated from Black Sea coastal waters of Romania, were evaluated for their bioactivity potential. The results from Cystoseira barbata were obtained: for total phenolic content obtained in ethanolic extracts (TPC): $385.6 \pm 1.85 \mathrm{mg}$ GAE/100 $\mathrm{g}$ f.w. Phenolic Acids quantified by HPLC-DAD from hydroethanolic extract of Cystoseira barbata from Black Sea was $80.14 \%$ from total phenolic contentidentified. We showed that Cystoseira barbata from the Romanian shore of the Black Sea contains vanillic acid in highest quantity ( $99.5 \pm 0.08 \mathrm{mg} / 100 \mathrm{~g}$ f.w.), followed by benzoic acid $(65.7 \pm 0.06 \mathrm{mg} / 100 \mathrm{~g}$ f.w.) and feluric acid (54.5 $\pm 0.01 \mathrm{mg} / 100 \mathrm{~g}$ f.w.). The smallest quantities were for gallic acid (3.5 $\pm 0.03 \mathrm{mg} / 100 \mathrm{~g}$ f.w.), pyrogallol acid (4.2 $\pm 0.05 \mathrm{mg} / 100 \mathrm{~g}$ f.w.) and 4-amino-benzoic acid (5.2 $\pm 0.09 \mathrm{mg} / 100 \mathrm{~g}$ f.w.). Cystoseira barbata has a total content of large phenols and also has strong antioxidant and antimicrobial activity. Antioxidant activity (ACL) was studied using DPPH radical scavenging activity and reducing power. The extracts containing high levels of total phenolic content were also potent DPPH radical scavengers. $T$. $I C_{5}$ $(\mathrm{ig} / \mathrm{mL}$ ) for Cystoseira barbata in methanolic extract was $942.92 \pm 2.56 \mathrm{ig} / \mathrm{mL}$. High absorbance obtained from reducing power assay indicates high reducing power, measured values of absorbance varied from 0.0901 at 0.9223 .
\end{abstract}

Keywords: brown seaweeds, Cystoseira barbata, antioxidant activity, total phenol content, HPLC-DAD

Marine algae are a large and varied group of phytoplankton found in the oceans of the world. There is a growing recognition that they are important sources of bioactive compounds with a variety of biological activities that could potentially contribute to functional pharmaceutical, food and nutraceutical industries [1 $\div 3]$. Different species of Cystoseira may present different phenologies that can also vary within the same species following the geographical distribution [4]. Cystoseira barbata (Stackhouse) C. Agardh (1820), is a brown macroalgae endemic to the Mediterranean, but it's also found in Black Sea water [4]. It has a thallus which consists of a perennial cauloid and a dendroid frond. Within its broad geographical range Cystoseira barbata may show considerable morphological and chemical variation, related to environmental conditions. Some studies were conducted on this species using traditional morphometric measures (length, biomass, age) in the Black Sea area [5]. Many studies show great variability in the chemical composition of marine algae characteristics due to marine habitats, but also other factors such as water temperature, seasonal variations, marine pollutants, etc. [6, 7]. Another problem is to what extent the differences in the ecological conditions could change the chemical composition of algae $[5,7]$. Many researchers have revealed that marine algae originated compounds exhibit various biological activities [8]. Many studies have been made on biological activities of the marine algae and were identified as potential sources of natural antioxidants $[9,10]$. The study of macroalgae grew up interest because of their ability for purification of associated ecosystems, and their role as bio-indicators

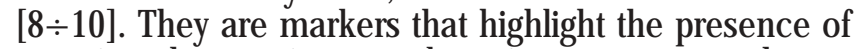
negative changes in coastal marine ecosystems due to the accumulation of pollutants in their tallus [11]. The
Cystoseira genus includes approximately 294 species [11, $12]$. Cystoseira are among the most dominant and ecologically important species in the Mediterranean and the Adriatic Sea [9:13]. In Black Sea we find the species Cystoseira barbata [11, 14, 15]. Previous investigation of members of the genus Cystoseira resulted in the discovery of a broad range of biological activities such as: antiinflammatory, antibiotics, antiprotozoal, antioxidant and cytotoxic activities [16]. Brown seaweeds represent a rich source of several nutraceuticals components like laminarans, fucoidans, and polyphenols. Among these, fucoidans, a sulphated polysaccharide has been the subject of much interest in recent years, mainly due to their pharmacological and biological potential with anti-viral $[17 \div 19]$, anti-cancer [20, 21], liver protection [22], antiinflammatory [23] and antibacterial [ 24,25$]$ properties and it also can affect the secretion of extracellular matrix proteins [26] and activate apoptosis [27 $\div 29]$. Cystoseira

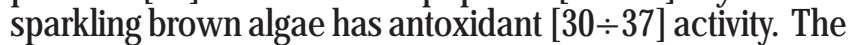
Black Sea has rich algae sources, but only a few studies of their biological activity are found in the literature [38]. The aim of this investigation is to provide chemical characterization and comparative analysis between samples of brown seaweed, Cystoseira barbata (Stackhouse) C. Agardh, taken from different locations in the Romanian shore of the Black Sea in Mangalia - 2 Mai Vama Veche area. Antioxidant activity correlated with chemical composition were studied.

\section{Experimental part \\ Plant materials}

The samples of seaweed were collected during J uneSeptember 2018, when algae reach maturity in different harvesting sites in the South region of the Romanian shore 
of the Black Sea. Analysis samples were harvested from 3 areas: S1 - Mangalia, S2 - 2 Mai and S 3 - Vama Veche. The collected sample was immediately taken to the laboratory in new plastic bags containing seawater to prevent evaporation. There, the sample was cleaned with fresh water and distilled water, then shade dried and powdered using an electric mixer. The powdered seaweeds were passed through a $0.5 \mathrm{~mm}$ sieve in order to obtain a uniform powder. The powdered sample was then stored in the freezer until extraction.

\section{Preparation of algal extract}

Extract in alcoholic solvent

The process of extraction was made by soaking algae's powder in alcoholic solvent ( $96 \%$ ethanol or $90 \%$ methanol), (1:10 w/v) for $24 \mathrm{~h}$. The received materials were concentrated in a rotary evaporator to reduce the volume. The received extracts were filtered through a Whatman paper No.1, three times, until a brown, clear extract and collected using a borosilicate glass container. The containers were placed in the refrigerator to be stored for future use.

\section{Chemicals}

All used reagents were of analytical reagent grade. Gallic acid was purchased from Fluka (Buchs, Switzerland) and Folin-Ciocalteu reagentfrom Merck (Darmstadt, Germany). All other reagents and standards used were purchased from Sigma-Aldrich (Sigma-Aldrich, Germany). Gram positive and gram negative bacteria strains were grown on culture media from the DSVSA microbiology laboratories in Constanta.

\section{Apparatus}

Spectrometric measurements were carried out using a UV-Vis Cintra 10e scanning spectrophotometer. The identification and quantitative determination of phenol compounds was performed using HPLC system (Agilent 1200 ) with quaternary pump, DAD, auto sampler.

Determination of total phenolic content (TPC) and chemical composition of pigments

The total polyphenol contents were determined using Folin-Ciocalteu reagent as described by Singleton et al. [39] with modifications. Nearly $500 \mathrm{~mL}$ of dilute extract from each sample was mixed with $2 \mathrm{~mL}$ Folin-Ciocalteu reagent (diluted 10 times with distilled water). After $5 \mathrm{~min}, 2.5 \mathrm{~mL}$ of sodium carbonate solution (7.5\%) was added and the mixture was allowed to stand for 90 min with intermittent shaking. The absorbance of the resulting solution was measured at $760 \mathrm{~nm}$ and compared to gallic acid calibration curve. The calibration curve was graphically represented by mixing $1 \mathrm{~mL}$ aliquots of $50,100,150,200$, $250,300,350,400$ and $450 \mathrm{mg} / \mathrm{L}$ gallic acid solutions with $5.0 \mathrm{~mL}$ of Folin-Ciocalteu reagent (1:10) and $4.0 \mathrm{~mL}$ of sodium carbonate $(75 \mathrm{~g} / \mathrm{L})$. Absorbance was measured after $30 \mathrm{~min}$ at $760 \mathrm{~nm}$. In order to determine total polyphenol content from ethanol extracts, $1 \mathrm{~mL}$ of sample was mixed with the same reagents as the ones used for the calibration curve.

\section{Calibration curve}

The calibration curve (fig. 1) was graphically represented by mixing $1 \mathrm{ml}$ aliquots of $50,100,150,200,250,300,350$, $400,450,500,550$ and $600 \mathrm{mg} / \mathrm{L}$ gallic acid solutions with $5.0 \mathrm{~mL}$ of Folin-Ciocalteu reagent (1:10) and $4.0 \mathrm{~mL}$ of sodium carbonate $(75 \mathrm{~g} / \mathrm{L})$.

Absorbance was measured after $30 \mathrm{~min}$ at $765 \mathrm{~nm}$. In order to determine total polyphenol content from ethanol extracts, $1 \mathrm{~mL}$ of sample was mixed with the same reagents as the ones used for the calibration curve. The characteristics of the calibration curve are given by the following equation: $Y=A * X+B ; A=0.0078 ; B=0.1842$; Correlation Coefficient $R^{2}=0.9999$. All samples were performed in triplicate and the mean value was reported.

\section{Identification of phenol acids by HPLC}

Identification of phenol acid was performed through a HPLC-DAD method. HPLC analysis of phenolic compounds, in the ethanolic extract of marine brown algae was determined according to the method described by Goupy [42]. The detection was conducted using high performance liquid chromatography (HPLC Agilent 1200 series) equipped with quaternary pump, auto sampler, column compartment set at $35^{\circ} \mathrm{C}$, multi wavelength detector set at $330 \mathrm{~nm}, 280 \mathrm{~nm}$. The column used was a Zorbax Eclipse XDB C18 analytical column ( $250 \times 4.6 \mathrm{~mm}$ ) (Agilent Technologies) with a $5 \mu \mathrm{m}$ packing material. Retention times and peak areas were monitored and computed automatically by Chem 32 integrator (Agilent). The retention time and standard deviations of phenolic standards chosen were: pyrogallol acid $(0.910 \pm 0.025)$, gallic acid $(0.990 \pm 0.03)$, protocatechuic acid $(3.130 \pm$ $0.008)$, 4-amino-benzoic acid (3.455 \pm 0.005$)$, chlorogenic acid (3.501 \pm 0.015$)$, p-hydroxybenzoic acid $(5.933 \pm 0.006)$, vanillic acid $(6.919 \pm 0.05)$, caffeic acid $(8.281 \pm 0.07)$, ferulic acid (8.865 \pm 0.06$)$, benzoic acid $(9.468 \pm 0.098)$, elagic acid (15.303 \pm 0.03$)$, and salicylic acid $(15.952 \pm 0.051)$, and for which a $0.05 \mathrm{mg} / \mathrm{mL}$ concentration was established. Individual phenol acids were identified by comparing the retention time of sample chromatographic peaks with those of authentic standards using the same HPLC-DAD operating conditions.

\section{Statistical analysis}

All experiments were conducted in triplicate $(n=3)$ and one-way ANOVA (using SPSS 11.5 statistical software) was used to compare the mean values of each treatment. Significant differences between the means of parameters were determined by using the Duncan test $(P<0.05)$.

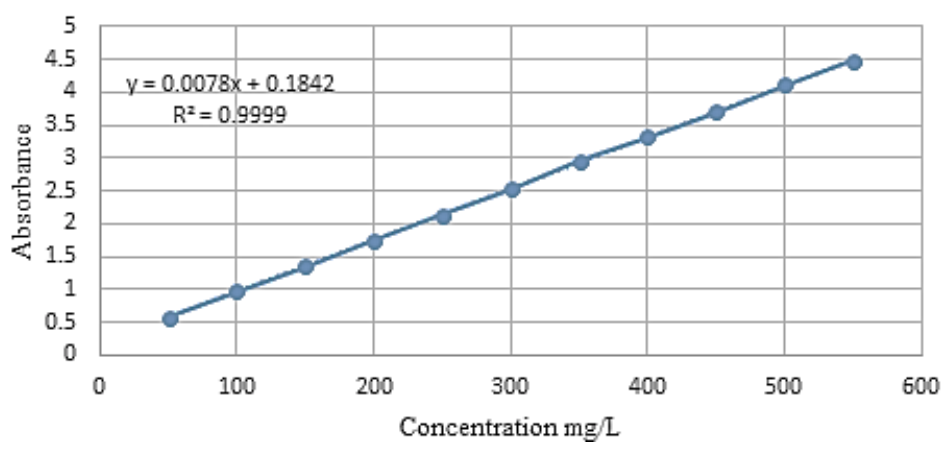

Fig.1. Calibration curve of Gallic acid 
Antioxidant activity - Screening of the extracts for Antioxidant activity ( $A C L)$

DPPH radical scavenging activity

The scavenging effect on the $\alpha$-diphenyl- $\beta$ picrylhydrazyl (DPPH) free radical was measured by the method described by Brand-Williams et al. [42]. Extracts of Cystoseira barbata seaweeds, in methanol were made. The $20 \mathrm{mg} / \mathrm{L}$ DPPH solution was dissolved in methanol, then left for $30 \mathrm{~min}$ for the reaction to occur. $1.5 \mathrm{~mL}$ of this solution was taken and $0.75 \mathrm{~mL}$ algae extract was prepared at different concentrations (250-1000 $\mu \mathrm{g} / \mathrm{mL}$ ). Absorbance was measured with a spectrophotometer at $517 \mathrm{~nm}$ after 30 min. Absorption of DPPH solution in methanol was also measured without any antioxidant (Control). The percentage of DPPH-scavenging activity was calculated using the following equation:

$$
\operatorname{DPPH}(\%)=\frac{A_{\text {control }}-A_{\text {sample }}}{A_{\text {Control }}} * 100
$$

where: $A_{\text {sample }}$ is sample absorbance after $30 \mathrm{~min}$. for the extract witth algae and DPPH sample and $A_{\text {control }}$ is DPPH absorbance without algae extract.

As a standard, 6-hydroxy-2, 5, 7, 8-tetramethyl-2carboxylic acid (Trolox) was used as a positive control. Concentrations in algal extracts that provided IC50 inhibition values (defined as the concentration of compounds capable of inhibiting 50\% of total DPPH radicals) were calculated from graphs using non-linear regression.

\section{The reducing power}

The power of reduction was measured according to Oyaizu's [43] method with some modifications. To $1 \mathrm{~mL}$ extract of Cystoseira barbata (at a concentration range of $250-1000 \mu \mathrm{g} / \mathrm{mL}$ ) was added $1 \mathrm{~mL}$ of $0.2 \mathrm{M}$ phosphate buffer $(p \mathrm{H}$ 6.6) and $1 \mathrm{~mL}$ of $1 \%$ potassium ferricyanide. The mixture was incubated at $50^{\circ} \mathrm{C}$ for $20 \mathrm{~min}$, and $1 \mathrm{~mL}$ of $10 \%$ acetic acid trichloride was added to this reaction mixture. A $2 \mathrm{~mL}$ aliquot of the incubation mixture was mixed with $2 \mathrm{~mL}$ of distilled water and $0.1 \mathrm{~mL}$ of $0.1 \%$ ferric chloride in test tubes. After 10 minutes, the solution was measured at $700 \mathrm{~nm}$ using a spectrophotometer. Ascorbic acid at a concentration of $200 \mu \mathrm{g} / \mathrm{mL}$ was used as a reference because it has a good reduction property. The increase in absorbance $(A 700)$ of the reaction mixture indicated the increase in reduction power. Values are expressed as mean $\pm \mathrm{SD}$ of three parallel measurements.

\section{Results and discussions}

\section{Total phenol content (TPC) and Pigments content}

Phenolic compounds are the secondary metabolites of algae which take part indirectly in physiological processes such as photosynthesis, reproduction and cell division. They are biosynthesized through the shikimic acid and acetatemalonate pathways [44]. The results of total phenol content (TPC) determined for ethanol extracts of Cystoseira barbata are presented in table 1. The results obtained by us are in accordance with the literature, among which: Sokmen et al. [15], Kosanic et al [32]. There are studies in literature which outline the fact that the type of solvent influences selectivity of phenol compounds [45]. The study performed by Wang, J onsdottir and Olafsdottir [46], shows that water is inferior to polar organic solvents in the extraction of polyphenolic compounds, which confirms our use of ethanol as a solvent.

These bioactive compounds isolated from marine algae have been reported with antibacterial, anti-inflammatory, antioxidant, anti-tumoral activity [16].
Table 1

TOTAL PHENOLIC COMPOUNDS CONTENTS OF ETHANOLIC EXTRACTS OF BROWN ALGAE CYSTOSEIRA BARBATA FROM BLACK SEA

\begin{tabular}{|l|c|}
\hline Sample & $\begin{array}{c}\text { Total phenolic TPC } \\
\text { mg. GAE } / 100 \text { g f.w. }\end{array}$ \\
\hline Cystoseira barbata & $385.6 \pm 1.85$ \\
(C.Agardh 1820) & \\
\hline \multicolumn{2}{|c|}{ Values are mean \pm SD }
\end{tabular}

\section{HPLC analysis of phenol compounds}

The phenol acids in the extracts were identified by HPLCDAD. Table 2 presents the individual phenol concentrations determined by HPLC - DAD expressed in $\mathrm{mg} / 100 \mathrm{~g}$ f.w. from Cystoseira barbata. In figure 2 The mean values of phenolic content identified and quantified in Cystoseira barbata from Black Sea are presented. By correlating the total phenol content (TPC) and individual phenols found through the HPLC-DAD technique, the majority phenol content can also be expressed as percentage (table 2). The standards used allowed the determination of phenol compounds present in the analyzed samples. It can be observed that the total phenols identified and quantified were in different procentages for the ethanol extracts from Cystoseira barbata. We showed that Cystoseira barbata. from the Romanian shore of the Black Sea contains vanillic acid in highest quantity $(99.5 \mathrm{mg} / 100 \mathrm{~g}$ f.w.), followed by benzoic acid (65.7 mg/100 g f.w.) and feluric acid (54.5 $\mathrm{mg} / 100 \mathrm{~g}$ f.w.). If we correlate the total phenol content (TPC) identified and quantified in the analyzed seaweed with the vanilic acid content found (table 3), it can be observed that vanilic acid has the highest percentage of total existing phenols (25.8\%), followed by benzoic acid $(17.00 \%)$ and feluric acid $(14.13 \%)$. The smallest quantities were for gallic acid $(3.5 \pm 0.03 \mathrm{mg} / 100 \mathrm{~g}$ f.w.), pyrogallol acid $(4.2 \pm 0.05 \mathrm{mg} / 100 \mathrm{~g}$ f.w.) and 4-aminobenzoic acid $(5.2 \pm 0.09 \mathrm{mg} / 100 \mathrm{~g}$ f.w.). Phenolic acid quantified by HPLC-DAD from hydroethanolic extract of

Table 2

THE INDIVIDUAL PHENOL CONCENTRATIONS DETERMINED BY HPLC - DAD IN BROWN SEAWEED FROM THE ROMANIAN BLACK

\begin{tabular}{|c|c|c|}
\hline \multicolumn{3}{|c|}{ SEA COAST } \\
\hline Type of acid & $\begin{array}{c}\text { Mean value } \pm S D \\
m g / 100 g \text { f.w. }\end{array}$ & $\begin{array}{c}\text { Procentage } \\
\%\end{array}$ \\
\hline Pyrogallol Acid & $4.2 \pm 0.05$ & 1.10 \\
\hline Gallic Acid & $3.5 \pm 0.03$ & 0.91 \\
\hline Protocatechuic Acid & $7.12 \pm 0.01$ & 1.85 \\
\hline 4-Amino-benzoic Acid & $5.2 \pm 0.09$ & 1.35 \\
\hline Chlorogenic Acid & $5.3 \pm 0.05$ & 1.37 \\
\hline p-Hydroxy-benzoic Acid & $26.9 \pm 0.06$ & 6.97 \\
\hline Vanillic Acid & $99.5 \pm 0.08$ & 25.80 \\
\hline Caffeic acid & $21.2 \pm 0.06$ & 5.49 \\
\hline Feluric Acid & $54.5 \pm 0.01$ & 14.13 \\
\hline Benzoic Acid & $65.7 \pm 0.06$ & 17.00 \\
\hline Ellagic Acid & $5.6 \pm 0.02$ & 1.45 \\
\hline Salicylic Acid & $10.5 \pm 0.03$ & 2.72 \\
\hline Total & 309.22 & 80.14 \\
\hline
\end{tabular}

Cystoseira barbata from Black Sea was $80.14 \%$ from total phenolic contentidentified.

Another acid found in significant amounts is represented by p-hydroxybenzoic acid ( $26.9 \mathrm{mg} / 100 \mathrm{~g}$ f.w $)$, caffeine ( $21.2 \mathrm{mg} / 100 \mathrm{~g}$ f.w.) and salicylic acid ( $10.5 \mathrm{mg} / 100 \mathrm{~b}$ f.w.) The remainder phenol acids which were identified and quantified through HPLC-DAD, were found in smaller amounts (fig.2). 


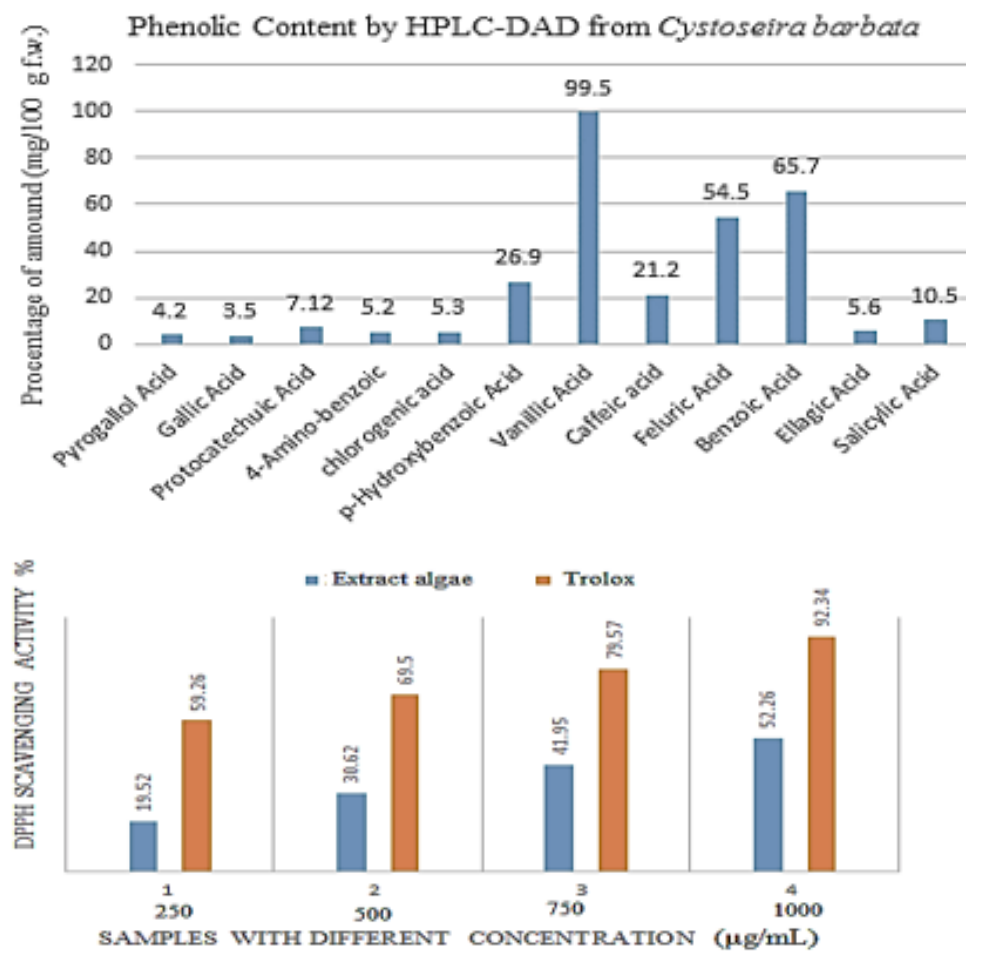

Fig. 2. The mean values of phenolic content identified and quantified in Cystoseira barbata from Black Sea

Table 3

THE PERCENTAGES (\%) OF TOTAL PHENOLS AND OF MAIOR PHENOL COMPOUND IDENTIFIED IN CYSTOSEIRA BARBATA FROM BLACK SEA BY HPLC-DAD REPORTED TO TPC VALUES

\begin{tabular}{|l|l|c|l|l|l|}
\hline $\begin{array}{l}\text { Total phenols } \\
\text { identified and quantified } \\
\%\end{array}$ & \multicolumn{5}{|c|}{ The major phenol compound identified and quantified } \\
\hline \multirow{2}{*}{80.14} & Phenol compound & $\%$ & Phenol compound & $\%$ & Phenol compound \\
\hline & Vanilic Acid & 28.8 & Benzoic Acid & 17.0 & Feluric Acid \\
\hline
\end{tabular}

Due to ditterent extraction methods, ditterent species studied, the measurements used and the lack of information regarding phenol composition of Black Sea algae in literature on the matter, a direct comparison between our results and studies performed in other seas is not feasible.

\section{DPPH radical scavenging activity}

DPPH assay is considered a valid accurate, easy and economic method to evaluate radical scavenging activity of antioxidants, since the radical compound is stable and doesn't have to be generated [48]. Sanchez-Moreno et al. [49] proposed a new methodology for the evaluation of antiradical efficiency towards DPPH, which is advantageous over other methods. It considers not only the antioxidant concentration but also the reaction time of scavenging reaction to reach the plateau. The results are highly reproducible and comparable to other free radical scavenging methods Gil et al. [50]. The percentage of inhibition DPPH has been quantified for different concentrations of the methanol extracts of Cystoseira barbata and for Trolox solutions as a reference. DPPH scavenging activity is presented in figure 3 .

The methanol extracts of Cystoseira barbata showed a significant dose-dependent reduction of DPPH radicals ( $P$ $<0.05)$. The mean values of DPPH (\%) range between $19.52 \%$ and $52.26 \%$ and rise with increasing concentrations from $250 \mu \mathrm{g} / \mathrm{mL}$ to $1000 \mu \mathrm{g} / \mathrm{mL}$ and are comparable to increases in Trolox solutions at the same concentrations (from 59.26 to $92.34 \%$ ), (fig 3). Free radical accepts an electron or hydrogen radical as DPPH being a stable, forming a stable diamagnetic molecule. The DPPH scavenging potential of Cystoseira barbata may be due to their reducing action, which might donate hydrogen to a free radical, reducing it to nonreactive species [51, 52]. The IC ${ }_{50}$ value was expressed in micrograms equivalents per $\mathrm{mL}$ of sample extracts,(table 4). All experiments were done in triplicate, and the results are expressed as mean \pm SD. A lower IC50 value indicates higher antioxidant activity and vice versa. The extracts containing high levels of total phenolic content were also potent DPPH radical scavengers, suggesting that algal polyphenols may be the

Table 4

IC50 $(\mu \mathrm{g} / \mathrm{mL})$ FOR CYSTOSEIRA BARBATA FROM BLACK SEA AND FOR STANDARD SOLUTION

\begin{tabular}{|l|l|}
\hline \multicolumn{1}{|c|}{ Solution } & $\mathrm{IC}_{50}(\mu \mathrm{g} / \mathrm{mL})$ \\
\hline Cystoseira barbata in methanolic extract & $942.92 \pm 2.56$ \\
\hline Trolox solution & $49.65 \pm 1.23$ \\
\hline * Average of 3 repeated experiments \pm standard deviation
\end{tabular}

principle constituents responsible for antioxidant properties of these extracts [45, 51].

The individual phenolic compounds present in the extracts were also important for the radical scavenging activity. Radical scavenging activity of phenolic compounds also depends upon their unique phenolic structure $[42,45]$.

\section{The reducing power}

The reducing property indicates that the antioxidant compounds are electron donors and can reduce the oxidised intermediates of lipid peroxidation process, and in that way the antioxidant can act as primary and secondary antioxidants [45]. The reducing power was concentration dependent and increased with rising the concentration. Figure 4 shows the reducing power $(0.0901$ at 0.9223 ) of the extracts concentration from $62.5 \mathrm{mg} / \mathrm{mL}$ 
to $1000 \mathrm{mg} / \mathrm{mL}$. Various antioxidant activities were compared to ascorbic acid. The results showed that standard antioxidant had stronger activity than tested samples. High absorbance indicates high reducing power. In various antioxidant activities there was a statistically

\section{REDUCING POWER}

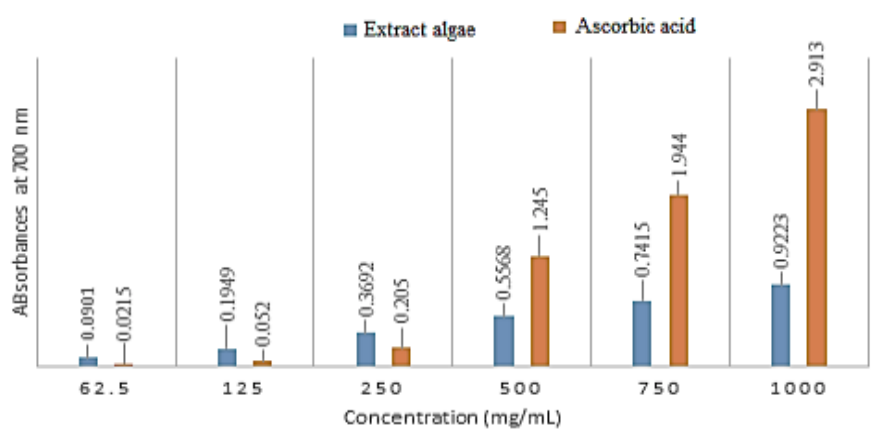

Fig. 4. Reducing power of methanolic extract of Cystoseira barbata and ascorbic acid solution

significant difference between extracts and control $(\mathrm{P}<$ 0.05).

Correlation between DPPH scavenging potential versus reducing power

There are many methods to determine antioxidant capacity. These methods differ in terms of their assay principles and experimental conditions; consequently, in different methods antioxidants in particular have varying contributions to total antioxidant potential [53]. In this study, the seaweed extracts antioxidant activities were tested using two different assays, DPPH scavenging and reducing power assays. These two methods represented different mechanisms of antioxidant action. The DPPH radical scavenging and reducing power assays showed positive and significantly high correlation $\left(R^{2}=0.9935\right)$, (fig. 5). The present data also revealed a significant antioxidant power potential of Cystoseira barbata from Black Sea. A significant

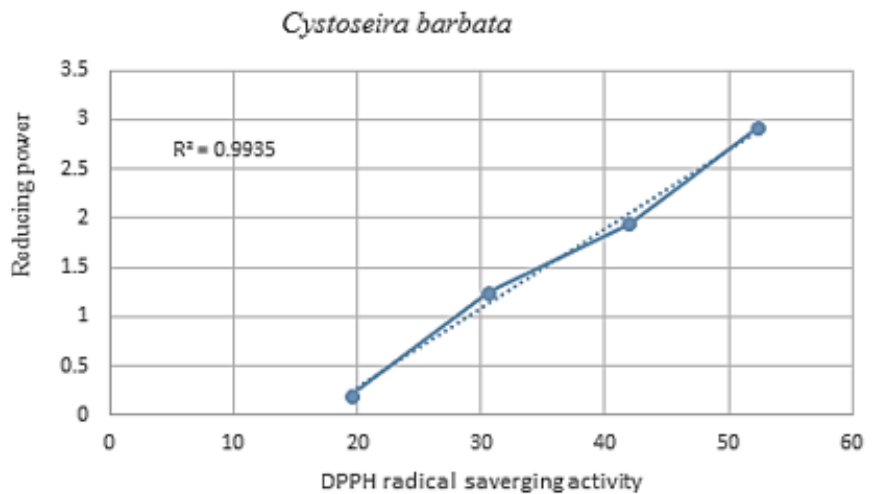

Fig. 5 Correlation of DPPH and reducing power values of seaweed methanolic extracts from Cystoseira barbata

correlation between DPPH scavenging potential vs reducing power was observed in Cystoseira barbata $(\mathrm{P}<$ 0.05 ) to support the above statement (fig. 5).

K.H. Sabeena Farvid and Charlotte J acobsen believe that the antioxidant properties of polyphenols are the result of their ability to act as reducing agents, hydrogen donors and free radicals and of caffenol's function as metal chelator, which impede the catalytic functioning of metal in the radical initiation process $[16,45]$.

As regards to the seasonal variation of bioactivity, for all of the taxa tested, spanish researchers say the autumn was the season with the highest percentage of active taxa against at leastone testmicroorganism, followed by spring 2688
[33]. The present study revealed that, ethanol is the better solvent for extracting the active substances of Cystoseira barbata, it was agreed with Abdel-Raouf, N., et al [34], and with Souhaili and Faid [54] who reported that Cystoseira $s p$. would possess an active antibacterial, antifungal and antimycotoxins extractible compounds in the ethanol which must be isolated and identified for possible uses in the biotechnological and therapeutic domain.

\section{Conclusions}

This study presents the results obtained in determining the total content of phenols and pigmentscorrelated with the research of the antioxidant and antimicrobial activity for Cystoseira barbata in the marine water from the Romanian Black Sea coast. For Cystoseira barbata (C.Agardh 1820), the total polyphenol content (385.6 \pm $1.85 \mathrm{mg}$. GAE/100 g f.w.) was determined by the FolinCiocalteu method. Using HPLC-DAD techniques 12 individual phenol compounds were found, in varying quantities, in all the analyzed algae. The highest quantities were obtained for: vanilic acid $(99.5 \pm 0.08 \mathrm{mg} / 100 \mathrm{~g}$ f.w.), benzoic acid $(65.7 \pm 0.06 \mathrm{mg} / 100 \mathrm{~g}$ f.w.), feluric acid $(54.5 \pm 0.01 \mathrm{mg} / 100 \mathrm{~g}$ f.w.). The smallest quantities were for gallic acid (3.5 $\pm 0.03 \mathrm{mg} / 100 \mathrm{~g}$ f.w.), pyrogallol acid $(4.2 \pm 0.05 \mathrm{mg} / 100 \mathrm{~g}$ f.w.) and 4-amino-benzoic acid $(5.2 \pm 0.09 \mathrm{mg} / 100 \mathrm{~g}$ f.w.).

Antioxidant activity, as determined using two different assays, DPPH scavenging and reducing power assays. These two methods represented different mechanisms of antioxidant action. For Cystoseira barbata in methanolic extract IC 50 was $942.92 \pm 2.56 \mu \mathrm{g} / \mathrm{mL}$. High absorbance obtained from reducing power assay indicates high reducing power, measured values of absorbance varied from 0.0901 at 0.9223 . The DPPH radical scavenging and reducing power assays showed positive and significantly high correlation $\left(R^{2}=0.9935\right)$. In conclusion, the result of the present study confirms that marine algae Cystoseira barbata is a potential source of bioactive compounds against various human pathogens, which can be used as natural non-toxic preservative and may be more acceptable to consumers.

\section{References}

1.THOMAS N.V., KIM S-K, Envir. Toxic. Pharm. 32, 2011, p. 325

2.SIRBU, R., TOMESCU A., JURJA, S., ERIMIA, C.-L., CADAR, E., $15^{\text {th }}$ SGEM, Proceedings Conference Bulgaria, I, 2015, p. 567.

3.FALACE, A., BRESSAN, G., Hydrobiol. 555, 2006, p. 193.

4.PIRAINO, S., FANELLI, G., BOERO, F., Mar. Biol. 140, 2002, p.1067. 5.MANNINO, A.M., VAGLICA, V., ODDO, E., J. Biol. Res. 90, 2017, p. 6578.

6.KAMENARSKA Z. YALCIN, F. N., ERSOZ, T., CALIS, I., STEFANOVA, K., POPOVA, S., J.Biosci. 57, (c), 2002, p. 584.

7.GOUVEIA, V., SECA, A.M., BARRETO, M.C., PINTO, D.C., Med. Chem., 13, 2013, p. 1150.

8.STANOJ KOVIC, T.P., KONIC-RISTIC, A., KLJAJIC, Z., GROZDANICSTANISAVLJEVIC, N., SRDIC-RAJIC, T., ZDUNIC, G., SAVIKIN, K.J. Nanomater. Bios. 9, 2014, p. 869.

9.MATANJUN, P., MOHAMED, S., MUSTAPHA, N.M., MOHAMMAD, K. AND MING, C.H. J. Appl. Phycol. 20, (4), 2008, p.367.

10.MANEV, Z., ILIEV, A., VACHKOVA, V., J. Agric. Sci., 1, Suppl. 2013, p.12

11.ROZIC, S., PUIZINA, J., SAMANIC, I., ZULJEVIC, A., ANTOLIC, B. Acta Adriat. 53, 2012, p. 447.

12.MHADHEBI, L., MHADHEBI, A., ROBERT, J., BOURAOUI, A. J. Pharm. Res. 13, 2014, p. 207.

13.TRICA, B., DELATTRE C., PIERRE, G., URSU A.V., GARDARIN C., MICHAUD, P., DJ ELVEH, G., DOBRE, T., Bull. Rom. Chem. Eng. Soc., 4, (2), 2017, p. 52. 
14.BILGIN SOKMEN, B, AYDIN, S, SAGKAL, Y, AKYURT, I.J. Sci. 6, (14), 2016, p.66.

15.WANG, D.H-M., LI, X-C., LEE, D-J., CHANG, J.S., Biores. Tech. 244, 2017, p. 1407.

16.ABDEL-RAOUF, N., AL-ENAZI, N.M., IBRAHEEM, I.B.M. AND ALHARBIE, R. M. J. Appl. Pharma. Scie, 5, (8), p.114.

17.AL-SAIF, S.S., ABDEL-RAOUF, N., EL-WAZANANI, H.A. AND AREF, I.A. J. Biol. Sci., 21, 2014, p. 57.

18.IBRAHEEM, B.M.I., NEVEEN, A.R., MOHAMED, S.A.H. AND KHALED, E.Y. J. Biotech., 11, 2012, p. 8332.

19.LIU J.M., BIGNON J., HAROUN-BOUHEDJA F., BITTOUN P., VASSY J., FERMANDJ IAN, S. Anticancer Res., 25, 2005, p. 2129.

20.GUTIERREZ-RODRIGUEZ, A.G., JUAREZ-PORTILLA, C, OLIVARESBANUELOS, T., ZEPEDA, R., C., Drug Disc. Today, 23, (2), 2018, p. 434 21.SAITO A, YONEDA M, YOKOHAMA S, OKADA M, HANEDA M, NAKAMURA K. Hepatol Res. 35, 2006, p. 190.

22.MARUYAMAA H, TAMAUCHIB H, HASHIMOTOC M, NAKANO T, Int. Arch. Allergy Immunol. 137, 2005, p.289.

23.TAJ BAKHSH, S., ILKHANI, M., RUSTAIYAN, A., LARIJ ANI, K., SARTAVI, K., TAHMASEBI, R., ASAYESH, G. J. Med. Plants Res, 5, 2011, p. 4654. 24.ZAPOPOZHETS, T.S, BESEDNOVA, N.N, LOENKO, I.N, Antibiot Khimioter., 40, 1995, p.9.

25.MOON HJ, PARK KS, KU MJ. J Nat. Prod. 72, 2002, p.1731.

26.SENTHILKUMAR K, MANIVASAGAN P, VENKATESAN J, KIM SK. Int J Biol. 60, 2013, p.366.

27.TOMESCU, A., TOMESCU, C. L., BREZEANU, D., PARIS, S., SIRBU, R., $3^{\text {th }}$ International-SGEM, Proceedings Conference, Bulgaria, II, 2016, p. 215.

28.TOMESCU, A., SIRBU, R., STANCIU, G., TOMESCU, C.L, J. Envir. Prot. Ecol., 15, (1), 2014. p. 303.

29. RUBERTO, G., BARATTA, M.T., BIONDI, D.M., AMICO, V., J. Appl. Phycol. 13, 2001, p. 403.

30.SELLIMI, S., KADRI, N., BARRAGAN-MONTERO, V., LAOUER, H., HAIJI, M., NASRI, M., International J. Biol. Macro. 66, 2014, p.281.

31.KOSANIC, M., RANKOVIC, B., STANOJ KOVIC, T., Acta Biol. Hungarica, 66, (4), 2015, p. 374.

32.SALVADOR, N., S., GOMEZ GARRETA, A., LAVELLI, L., RIBERA M., A., Sci. Marina, 71, (1), 2007, p.101.

33.ABDEL-RAOUF, N., MOHAMED, H.M., MOSTAFA, S.S., IBRAHEEM, B.M.I., J. Bot., 57, No.3, 2017, p. 469.
34.SABRINE SELLIMI, S.A.A., BENSLIM, A., BARRAGAN-MONTERO V.B., HAJJI, A.M, NASRI, M., International J. Biol. Macro., 105, 2017, p. 1375 35.OZDEMIR, G., HORZUM, Z., SUKATAR, A., KARABAYYAVASOGLU, N. U., Pharma. Biol., 44, (3), 2006, p. 183.

36.BECHIR, A., SIRBU, R., PACURAR, M., PODARIU, A.C., MONEA, M., BECHIR, E.S., GHERGIC, D.L., Rev. Chim. (Bucharest), 65, no.3, 2014, p.362.

37.HORINCAR, V.B., PARFENE, G., BAHRIM, G., Biotech. Letters, 16, no.6, 2011, Suppl., p. 71

38.SLINKARD, K., SINGLETON, V., Amer. J. Enol. Vitic., 28, 1997, p. 49. 39.LICHTHENTHALER, H.K., BUSCHMANN, C, Curr. Protoc. Food Anal. Chem. (CPFA), F4.3 (1 -8), (Suppl. 1), 2001. p.1.

40.GOUPY, P., HUGUES, M., PATRICK BOIVIN, P., AMIOT, M.J ., J. Sci. Food Agric., 79, (12), 1999, p.1625.

41.BRAND -WILLIAMS, W., CUVELIER, M.E., BERSET, C., Lebensm.Wiss. U.-Tech., 28, 1995, p.25.

42.0YAIZU, M., Jap. J. Nutrit., 44, 1986, p.307.

43.FERNANDO, I.S., KIM, M., SON, K. T., J EONG, Y., JEON, Y.J ., 2016. J. Med. Food. 19, (7), 2016, p.615.

44.FARVIN, S.K.H., JACOBSEN C., Food Chemistry 138, 2013, p. 1670. 45.WANG, T., JONSDOTTIR, R., OLAFSDOTTIR, G., Food Chem.116, 2009, p.240

46.KRAAN, S., Functional Ingredients from Algae for Foods and Nutraceuticals; Domínguez, H., Ed.; Woodhead Publishing: Cambridge, UK, 2013, p. 205-251.

47.KEDARE, S.B., SINGH, R.P., J Food Sci. Technol., 48, (4), 2011, p.412.

48.SANCHEZ-MORENO, C., Food Sci Technol Int, 8, (3), 2002, p.121 49.GIL, MI, THOMAS BARBERAN, F.A., HESS-PIERCE, B, KADER, A.A., J Agric Food Chem. 50, (17), 2002, p.4976.

50. NAVNATH, M., PISE, K., JENA, B., DUSHMANT, M., SABALE, A.B., JAGTAP, T.G., J. Algal Biomass Utln., 1, (2), 2010, p. 60.

51.MATANJUN, P., MOHAMED, S., MUSTAPHA, N.M., MUHAMMAD, K., MING C. H., J. Appl. Phycol, 20, 2008, p. 367.

52.TASKIN, E., OZTURK, M., TASKIN, E., KURT, O., Afric.J. Biotech, 6, (24), 2007, p. 2746.

53.OSMAN, M.E.H., ABOSHADY, A.M., ELSHOBARY, M.E., Afric. J. Biotech, 12, no.49, 2013, p. 6847.

54.SOUHAILI1, Z., FAID, M., J Microbiol., 3, (1), 2016, p.1.

Manuscript received:24.11.2018 